\section{'Lane': An Early-season Self-fertile Black Muscadine Grape}

\author{
Patrick J. Conner ${ }^{1}$ \\ University of Georgia, 4604 Research Way, Tifton, GA 31793
}

Additional index words. Vitis rotundifolia, breeding, Muscadinia rotundifolia

The genus Vitis L. contains two subgenera, Euvitis Planch. (bunch grapes) and Muscadinia Planch. (muscadine grapes). The muscadine grape, Vitis rotundifolia Michx., is the only commonly cultivated member of the Muscadinia subgenus. The muscadine grape differs from the common bunch grape (Vitis labrusca L., $V$. vinifera L., and their various hybrids) by the presence of smaller clusters, unbranched tendrils, berries with thick skins, and a unique fruity aroma. Muscadine grapes are an important fruit crop in the southeastern United States where Pierce's disease (Xylella fastidiosa Wells et al.) and other diseases limit the production of most bunch grape cultivars. 'Lane' is a new muscadine grape cultivar released by the University of Georgia College of Agriculture and Environmental Sciences. 'Lane' has self-fertile flowers and produces black berries of large size that ripen early in the muscadine harvest season. High soluble solids and excellent berry firmness make 'Lane' a good choice for fresh market sales. As a result of its medium yields, 'Lane' plantings should probably be restricted to what is required to meet early-season sales.

\section{Origin}

'Lane' originated in Tifton, GA, from a cross of 'Supreme' by 'Tara' made in 2005 by Patrick Conner at the University of GeorgiaTifton Campus. The pedigree of 'Lane' involves mostly University of Georgia-developed germplasm (Fig. 1). 'Supreme' has female flowers and produces a black berry with exceptional size and firmness (Conner, 2009). 'Tara' has self-fertile flowers and produces bronze berries with dry pedicel scars that ripen early in the muscadine harvest season (Conner, 2009; Lane, 1993). The original 'Lane' vine first fruited in 2007. Because of its self-fertile flowers, early harvest date, excellent flavor, and the characteristic of the flesh adhering to the skin, it was propagated for further trials as Georgia 5-1-45.

\section{Description and Performance}

Testing locations were Tifton, GA (lat. $31^{\circ} 28^{\prime} 39.81^{\prime \prime} \mathrm{N}$, long. 8331'39.61" W), Ocilla, GA (lat. $31^{\circ} 32^{\prime} 46.59^{\prime \prime} \mathrm{N}$, long. $83^{\circ} 4^{\prime} 49.04^{\prime \prime} \mathrm{W}$ ), and Watkinsville, GA (lat.

Received for publication 19 Oct. 2012. Accepted for publication 17 Nov. 2012.

${ }^{1}$ To whom reprint requests should be addressed; e-mail pconner@uga.edu. Tifton and Watkinsville trials where vines were $3 \mathrm{~m}$ apart and trained to a $1.5-\mathrm{m}$ high

Fig. 1. Pedigree of 'Lane' muscadine. third, fourth, and fifth years of fruiting.

$\mathrm{NS}=$ nonsignificant. bilateral cordon, vines reached the wire and most of the cordons were established in the first year. Leaves average $10 \mathrm{~cm}$ in length and $8.5 \mathrm{~cm}$ in width. Lateral canes are semidrooping and usually grow $1 \mathrm{~m}$ or more in a season in Tifton, GA. Typical cane diameter is $\approx 3$ to $12 \mathrm{~mm}$ and internode length ranges from 3 to $6 \mathrm{~cm}$. Yields from 'Lane' were lower than the other self-fertile cultivars tested (Table 1). The reduced cropload was likely the result of fewer canes being produced as well as a smaller cluster size. 'Lane' did not increase in yields after vines had extended down wire to form the main cordons in Year 3, whereas 'Tara' and 'Nesbitt' continued to increase in yield. This is despite the fact that vine vigor, as measured by trunk caliper, was similar among the three cultivars (Table 1). Altered pruning may be necessary to optimize yield potential in 'Lane', perhaps by increasing the number of buds left on the vine.

Harvest date for 'Lane' is very early corresponding to the last week of July or first week of August in Tifton, GA. This is $\approx 10$ to $14 \mathrm{~d}$ before 'Supreme', the primary blackfruited fresh-market muscadine grown in south Georgia. At maturity, the berries of 'Lane' are round and average $11.0 \mathrm{~g}$ in weight and $26.1 \mathrm{~mm}$ in diameter (Table 2) with four seeds per berry. Berry size of 'Lane' is similar

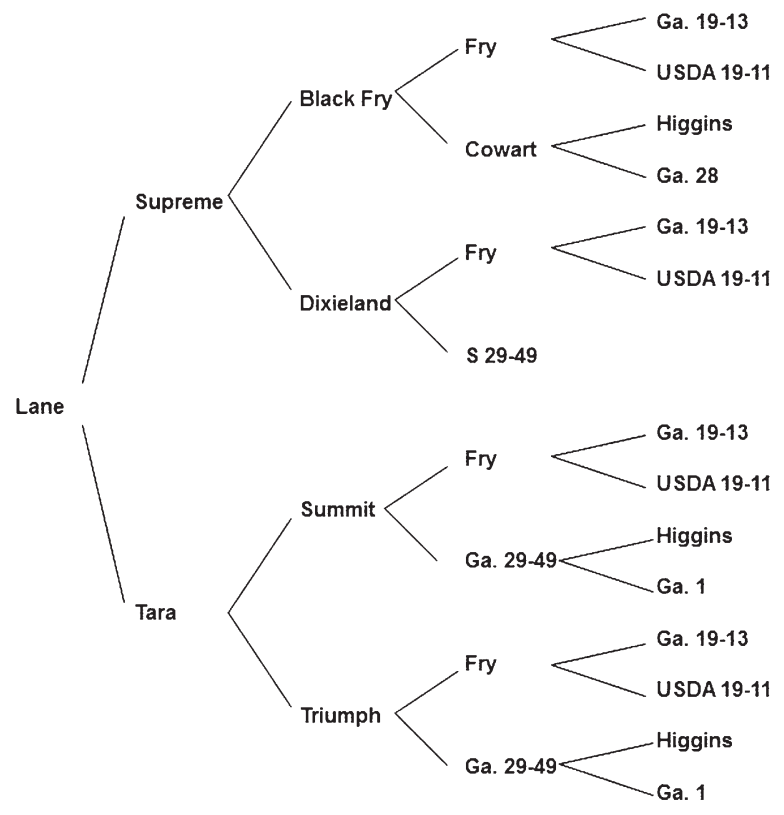

Table 1. Vine caliper ( $\mathrm{mm}$ ) and yield ( $\mathrm{kg} / 3-\mathrm{m}$ vine) of self-fertile muscadine cultivars in Tifton, GA, in the

\begin{tabular}{lcccccc}
\hline Cultivar & $\begin{array}{c}2010 \text { caliper } \\
(\mathrm{mm})^{\mathrm{z}}\end{array}$ & $\begin{array}{c}2010 \text { yield } \\
(\mathrm{kg})\end{array}$ & $\begin{array}{c}2011 \text { caliper } \\
(\mathrm{mm})\end{array}$ & $\begin{array}{c}2011 \text { yield } \\
(\mathrm{kg})\end{array}$ & $\begin{array}{c}2012 \text { caliper } \\
(\mathrm{mm})\end{array}$ & $\begin{array}{c}2012 \text { yield } \\
(\mathrm{kg})\end{array}$ \\
\hline Lane & 15.9 & 14.4 & 24.7 & $10.8 \mathrm{~b}$ & 30.7 & $13.0 \mathrm{~b}$ \\
Tara & 19.7 & 17.6 & 28.2 & $21.7 \mathrm{a}$ & 29.8 & $33.0 \mathrm{a}$ \\
Nesbitt & 17.2 & 11.6 & 27.2 & $20.1 \mathrm{a}$ & 32.9 & $29.8 \mathrm{a}$ \\
Significance & $\mathrm{yS}$ & $\mathrm{NS}$ & $\mathrm{NS}$ & 0.004 & $\mathrm{NS}$ & 0.003 \\
\hline
\end{tabular}

${ }^{2}$ Caliper measured on the trunk $75 \mathrm{~cm}$ above the ground before budbreak.

${ }^{\mathrm{y}}$ Mean separation within columns by Duncan's multiple range test, $P<0.05$, with $\mathrm{n}=4$. 
to that of other commercially used self-fertile cultivars such as 'Nesbitt' and 'Tara' and the industry-leading female cultivar, Fry, but is smaller than the very large-fruited 'Supreme' (Table 2). The color of 'Lane' berries is very dark purple to near black at peak ripeness with inconspicuous lenticels, and berries are well colored even near the pedicel attachment point (Fig. 2). Berries have an excellent soluble solids content of $17.6 \%$ (Table 2) and are noticeably sweeter than other cultivars early in the harvest season. Like its female parent, 'Supreme', 'Lane' has a very firm flesh texture, and 'Lane' berries hold their firmness well during storage (Table 3). Some skin tearing around the pedicel scar occurs, similar to the other cultivars tested (Table 2), but the firmness of the flesh decreases the amount of juice that leaks from the injury.

Symptoms of Pierce's disease have not been observed on 'Lane' at any location. Under a typical fungicide schedule, very low levels of infection with bitter rot [Greeneria uvicola (Berk. \& Curt.) Punithalingam, syn. Melanconium fuligineum (Scribner \&Viala) Cav.], ripe rot [Glomerella cingulata (Stonem.) Spauld. \& Schrenk], and macrophoma rot [Botryosphaeria dothidea (Moug. Ex Fr.) Ces. \& de Not] were observed. Infection levels were similar to 'Supreme' and better than 'Tara', 'Fry', and other bronze-fruited cultivars. Angular leaf spot (Mycosphaerella angulata Jenkins) was observed during the late season at levels similar to the other cultivars tested.

'Lane' is recommended as an earlyseason black muscadine for the fresh market. Although 'Lane' berries are smaller than 'Supreme', berry size is similar to most other successful fresh-market cultivars. Appearance of 'Lane' in clamshells is excellent as a result of a consistent berry size and very dark, evenly colored berries. As a result of its lower yields, 'Lane' is only recommended for the early market, before other black muscadines become available. Currently, growers in south Georgia enter the early market by picking the very first berries to ripen on 'Supreme'. This requires multiple harvests of 'Supreme' resulting in high labor costs. 'Lane' ripens relatively uniformly and can be harvested with two pickings at the beginning of the season. Growers could then move into 'Supreme' as the main season cultivar when a greater percentage of berries is ripe. The similar flesh quality between 'Lane' and 'Supreme' should facilitate their use in the same market. Although no cold damage has been observed in the south Georgia or Watkinsville, GA, trials, 'Lane' needs to be trialed more thoroughly in northern muscadine production regions before large plantings

Table 2. Flower and fruit attributes of 'Lane' and standard muscadine cultivars at Tifton, GA, in years 2010-12.

\begin{tabular}{lllcccc}
\hline Cultivar & Flower type & Berry color & $\begin{array}{c}\text { Berry } \\
\mathrm{wt}(\mathrm{g})^{\mathrm{z}}\end{array}$ & $\begin{array}{c}\text { Berry diam } \\
(\mathrm{mm})^{\mathrm{z}}\end{array}$ & $\begin{array}{c}\text { Percent soluble } \\
\text { solids }^{\mathrm{z}}\end{array}$ & $\begin{array}{c}\text { Percent } \\
\text { dry scar }^{z, y}\end{array}$ \\
\hline Lane & SF & Purple & $11.0 \mathrm{bc}$ & $26.1 \mathrm{~b}$ & $17.6 \mathrm{a}$ & 59.6 \\
Nesbitt & SF & Purple & $9.8 \mathrm{c}$ & $26.1 \mathrm{~b}$ & $13.5 \mathrm{c}$ & 55.1 \\
Supreme & F & Purple & $14.7 \mathrm{a}$ & $29.3 \mathrm{a}$ & $14.7 \mathrm{bc}$ & 60.3 \\
Fry & F & Bronze & $12.0 \mathrm{~b}$ & $27.3 \mathrm{~b}$ & $15.0 \mathrm{bc}$ & 60.1 \\
Tara & SF & Bronze & $10.9 \mathrm{bc}$ & $25.6 \mathrm{~b}$ & $15.4 \mathrm{~b}$ & 83.0 \\
Significance & & & $<0.001$ & $<0.001$ & 0.001 & NS \\
\hline
\end{tabular}

${ }^{\mathrm{z}} \mathrm{A}$ 10-berry sample was taken from each harvest to calculate berry attributes. Mean separation within columns by Duncan's multiple range test, $P<0.05$, with $\mathrm{n}=4$.

${ }^{y}$ Dry scars represent the lack of skin tears or openings around the pedicel scar after picking. $\mathrm{NS}=$ nonsignificant.

$\mathrm{SF}=$ self-fertile, $\mathrm{F}=$ female .

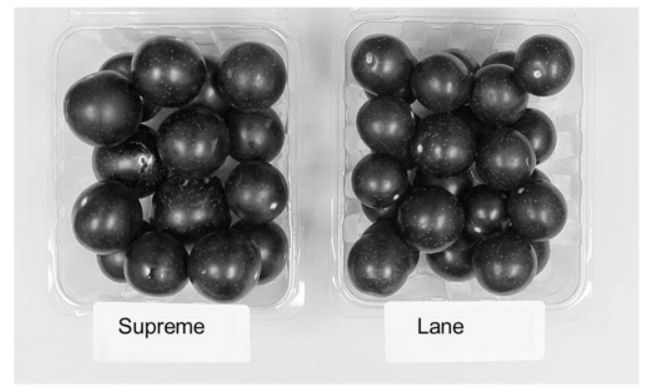

Fig. 2. Ripe berries of 'Supreme' and 'Lane' muscadine in pint clamshells.

Table 3. Change in firmness $\left(\mathrm{g} \cdot \mathrm{mm}^{-1}\right)$ of 'Lane' and test cultivars at harvest and after cold storage $\left(0-1{ }^{\circ} \mathrm{C}\right.$, $90 \%$ to $95 \%$ relative humidity). ${ }^{\mathrm{z}}$

\begin{tabular}{|c|c|c|c|}
\hline Cultivar & $\frac{\text { Firmness }\left(\mathrm{g} \cdot \mathrm{mm}^{-1}\right)^{\mathrm{y}}}{\text { Day } 0}$ & $\frac{\text { Firmness }\left(\mathrm{g} \cdot \mathrm{mm}^{-1}\right)^{\mathrm{y}}}{\text { Day } 14+1}$ & $\frac{\text { Firmness }\left(\mathrm{g} \cdot \mathrm{mm}^{-1}\right)^{\mathrm{y}}}{\text { Day } 14+4}$ \\
\hline$\overline{\text { Lane }}$ & $396 \mathrm{~b}$ & $275 \mathrm{a}$ & $258 \mathrm{a}$ \\
\hline Supreme & $446 \mathrm{a}$ & $309 a$ & $267 a$ \\
\hline Tara & $303 \mathrm{c}$ & $209 \mathrm{~b}$ & $186 \mathrm{~b}$ \\
\hline Fry & $291 \mathrm{c}$ & $\mathrm{ND}^{\mathrm{x}}$ & $164 \mathrm{~b}$ \\
\hline Significance & 0.001 & 0.007 & 0.001 \\
\hline
\end{tabular}

${ }^{\mathrm{z}}$ Berries were evaluated at harvest, packaged in ventilated clamshell containers, and placed in cold storage for 2 weeks. Berries were then brought out of cold storage allowed to warm for $24 \mathrm{~h}$ at room temperature $\left(21^{\circ} \mathrm{C}\right)$ and evaluated 1 and $4 \mathrm{~d}$ post-removal.

'Values are means with $\mathrm{n}=4$ for 'Lane' and 'Supreme' and $\mathrm{n}=2$ for 'Tara' and 'Fry'. Each replication consisted of 25 berries measured for firmness using a Bioworks FirmTech II. Mean separation within columns by Duncan's multiple range test, $P<0.05$.

${ }^{\mathrm{x}}$ Fry firmness values were not determined at this time period as a result of experimental error.

are made in these locations. 'Lane' is easily propagated by softwood cuttings rooted under mist during June and July.

\section{Availability}

'Lane' will be a patented cultivar (U.S. patent applied for) and is owned by the University of Georgia Research Foundation. Propagation rights are controlled by the University of Georgia Research Foundation, Technology Commercialization Office, GSRC Boyd Building, Athens, GA 30602-7411 $(<$ http://www.ovpr.uga.edu/tco/ $>$ ). A list of nurseries licensed to propagate 'Lane' muscadine can be obtained by contacting the author.

\section{Literature Cited}

Conner, P. 2009. Performance of muscadine grape cultivars in southern Georgia. J. Amer. Pom. Soc. 63:101-107.

Lane, R. 1993. 'Tara' muscadine grape. HortScience 28:232

Poling, B., C. Mainland, W. Bland, B. Cline, and K. Sorenson. 2003. Muscadine grape production guide. N.C. State Ext. Serv. Bul. AG-94, Raleigh, NC. 